\title{
THE APPLICABILITY OF THE USUUL AL-FIQH PRINCIPLE “ISTIŞHÂB” TO THE PRESUMPTION OF DEATH OF A MISSING PERSON IN ISLAMIC LAW OF SUCCESSION AND MALAYSIAN LAW
}

\author{
Mohamad Asmadi Abdullah*
}

\begin{abstract}
The rights of inheritance do not arise until and unless the death of the praepositus and the survival of legal heirs are legally established. These two conditions may be easy to ascertain, but are in fact problematic when dealing with the case of uncertainty of death such as a missing person, because the death is not known. The ascertainment of death and the survival of legal heirs in a missing person case is extremely important because it determines whether any rights of inheritance exist or not. This article seeks to examine the principle of Ușul al-Fiqh "Istișâb" and the approaches undertaken by Muslim scholars to ascertain the related rights of succession involving missing persons. The article analyzes the relevant legal aspects of the applicable laws in Malaysia pertaining to the succession involving a missing person either as a praepositus or a legal heir. It also examines the jurisdictional conflict between the civil
\end{abstract}

Assistant Professor, Ahmad Ibrahim Kulliyyah of Laws, International Islamic University Malaysia. 
court and the Syariah court in Malaysia pertaining to the presumption of missing person's death in relation to Islamic law of succession.

Keywords: Istiṣhâb, Uṣûl al-Fiqh, Islamic Law of Succession, Farâ‘ị, Islamic Wealth Management, Islamic Law of Inheritance, Rights of a Missing Person (al-Mafqûd) in Inheritance, Islamic Jurisprudence.

\section{INTRODUCTION}

For Muslims, distributing their wealth upon death following the prescribed law i.e. the farâ 'id is a religious obligation. Before the distribution takes place, determining the rightful recipients who shall inherit the wealth is equally important. In order to ascertain the rightful legal heir, it is necessary that the pillars, conditions, causes and impediments of succession are taken into consideration. In other words, the distribution of property according to the farâ'i $i d$ system is based on comprehensive principles, merely to determine the rightful recipient as laid down by the Sharîcah.

Prior to the distribution, the death of the praepositus must be legally established. The missing person's case as far as inheritance is concerned, is an example of the relevance of the Ușûl al-Fiqh principle "Istiṣ̂âb" to ascertain the rightful recipient. In normal circumstances, one's death is established by the testimony of at least two trustworthy witnesses who have witnessed the event of death. However, in the missing person's case, the appropriate course of action is to refer the matter to a court of law, which after due investigation, may pronounce death. This pronouncement of the court is valid from the Islamic point of view as long as it is based on the recognized principle. ${ }^{1}$

The same principle applies to the determination of the survival of legal heirs. The whole estate can simply be distributed if there is no uncertainty regarding the death of a missing legal heir. In this case, it is important to establish that the heir is alive at the time of the deceased's death in order to realize his right of succession. However, in the absence

1 Khalîfah, Muhammad Ṭâhâ Abû al-cUlâ, Ahkâm al-Mawârîth 1400 Mas'alah Mîrâthiyyah, al-Qâhirah: Dâr al-Salâm, n.d., p. 8. 
of any legally acceptable evidence of his survival, the pronouncement of his death by the court will resolve the problem.

\section{THE GENERAL CONCEPT OF THE ISLAMIC LAW OF SUCCESSION}

In Arabic, the Islamic law of succession is commonly known as al-farâ ' $i d$, which literally means fixed portions. ${ }^{2}$ Farada is the root word

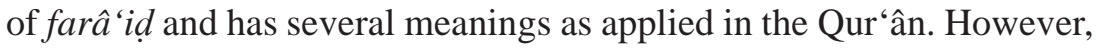
in relation to the present subject, the term denotes al-taqdîr, which literally means determination as applied in the Qur'anic verse al-Baqarah (2):237. ${ }^{3}$ Technically, according to al-Sharbînî, the term denotes the quantum of shares allotted to legal heirs as determined by the Sharî ${ }^{c} a h .^{4}$ Ibn 'Âbidîn explains that the knowledge of farâ'id is to do with the principles regarding determining the entitled legal heirs, their quantum of shares, the impediments and the causes of inheritance, the exclusions from inheritance and the classification of the legal heirs. ${ }^{5}$

As a divine law, its primary or epistemological sources are the Qur'ân and the Sunnah of the Prophet Muhammad. The principles and conditions regarding the devolution of a deceased Muslim's estate are deduced from the above sources. The Qur'ân and the Sunnah prescribe in detail the entitlement and the quantum of shares of each legal heir. There are three Qur'anic verses, known as the verses of inheritance that elucidate in detail matters of inheritance, namely sûrah al-Nisâ ${ }^{6}$

$2 \quad$ First Encyclopedia of Islam 1913-1936, New York: Leiden, Brill, E.J., 1965, vol. iii, p. 783. See also Musțafâ, Ibrâhîm, et.al., al-Muc jam alWasît, Istanbul: Al-Maktabah al-Islâmiyyah, n.d., p. 683.

$3 \quad$ The Qur'ân, al-Baqarah (2): 237; “And if you have divorced them before you have touched (had a sexual relation with) them, and you have fixed (faradtum) unto them the mahr (bridal-money given by the husband to the wife at the time of marriage)..."

$4 \quad$ Al-Sharbînî, Muhammad al-Khatîib, Mughnî al-Muhtâj, Egypt: Muștafâ al-Bâbî al-Ḥalabî̀, 1958, vol.3, p.2.

5 Ibn 'Âbidîn, Hâshiyah Rad al-Mukhtâr calâ Dur al-Mukhtâr, $3^{\text {rd }}$ edition, Bâkjistân: Maktabah Rasyîdiyyah Ku'tah, vol. 5, 1404H, p. 534. 
(4): 11, 12 and 176. In summary, these verses explain and prescribe entitled legal heirs, their respective portions of shares, the principle of 2:1 ratio between male and female legal heirs and the need to settle the rights attached to the estate prior to the distribution. It is a distinctive feature of this branch of Islamic law that in the main, the very detailed explanation and prescription of the principles are contained in the Qur'ân, as compared to other branches of Islamic law. Referring to this subject, Coulson states: "nowhere is the fundamental Islamic ideology of law as the manifestation of the divine will more clearly demonstrated than in the laws of inheritance."6

The Sunnah elaborates further the general inheritance rules, and in some cases introduces new principles that are not expressly mentioned in the Qur'ân. For instance, the rule of priority in succession, ${ }^{7}$ the principle of the completion of 2/3 between a daughter and son's daughters, ${ }^{8}$ the entitlement of the maternal grandmother ${ }^{9}$ and the entitlement of the bayt al-mâl (the state treasury) to the estate. ${ }^{10}$

Apart from the Qur'an and the Sunnah, the inheritance law draws its epistemological sources from ijmâ $\hat{a}^{c}$ or the consensus of Muslim jurists, and individual ijtihâds or reasonings. These two sources are applicable in situations where no clear injunction is found in the primary

$6 \quad$ Coulson, N.J., Succession in the Muslim Family, London: Cambridge University Press, 1971, p. 3.

$7 \quad$ The hadith "Gives the farâ' $i d$ (the shares of the inheritance that are prescribed in the Qur'ân) to those who are entitled to receive it. Then whatever remains, should be given to the closest male relative of the deceased." See Șahîh al-Bukhârî, translated by Khân, Muhammad Muhșin, The Translation of the Meanings of Sahị̣̂h al-Bukhârî, Riyâḍ: Dâr al-Salâm, 1997, vol. 8, p. 385.

$8 \quad$ The hadith "The Prophet applied the principle of the completion of the maximum 2/3; daughter is entitled to $1 / 2$ and son's daughter is entitled to 1/6." See Khân, Muhammad Muhsin, The Translation of Sahịh alBukhârî, vol. 8, p. 387.

The hadith "The Prophet gave portion 1/6 to the grandmother in the absence of mother.” See Khân, p. 378.

$10 \quad$ The hadîth "I am the legal heir of the person who dies without any legal heir." This implies that the property would be inherited by the bayt al-mâl because the Prophet does not inherit anything for himself but for the community of Muslim. See al-Sharbînî, Mughnî al-Muhtâj, p. 4-5. 
sources. In this case, Muslim jurists perform ijtihâd, which is clearly based on the principles deduced from the Qur'ân and the Sunnah, in order to solve newly arising problems encountered by Muslims. Some examples are the ijtihâd of 'Umar on the entitlement of paternal grandmothers, and in the case of al-gharâwayn, the interpretation of Abû Bakr on the meaning of al-kalâlah and the principles of almushârakah by 'Alî, Zayd and Ibn 'Abbâs. ${ }^{11}$

The entitlement of each recipient to the estate is based on their legitimate relationships with the deceased. Islamic law has established specific criteria that must be met for a relationship to be legitimate and to enable the survivor to inherit from the deceased. From the facts regarding the entitlement of legal heirs, it is understood that primarily, the marriage relationship, the blood relationship and the religion-based relationship are the relationships that are recognized by Islamic law to be the basis of inheritance. ${ }^{12}$ These relationships are important in determining the legal heirs of the deceased. For instance, a divorced wife should not be simply dismissed from inheritance because of the divorce. The nature of the divorce, either revocable or irrevocable, should be taken into account because this determines whether the marriage relationship remains or has ceased to exist. If a husband dies within the period of ciddah (waiting) of his divorced wife, the latter is still entitled on the grounds that the marriage relationship between them remains in existence, albeit constructively.

Another example is in the case of a blood relationship; the issue of the legitimacy of birth from the perspective of Islamic law is vital and determines the legal paternity of a child. This means that a child born within the period of less than 6 months of a marriage contract, or of the

11 cAtiyyah, Muhammad Tâhâ Abû al-Hâj, Dawâbit al-Irth fî al-Tashrî́c al-Islâmî. $3^{\text {rd }}$ edition, n.p.: Dâr al-Thaqâfah al-c'Arabiyyah, 1981, p. 26. See also Barrâj, Jumªh Muhammad, Ahkâm al-Mawârîth fí al-Sharî‘ah al-Islâmiyyah, 'Ammân: Dâr al-Fikr li al-Nashr wa al-Tawzî́c, 1981, pp. 35.

12 See al-Sharbînî, p. 4. Besides the three criteria, there are another two, namely relationships arising from the emancipation of a slave and from an oath of allegiance. The former has become irrelevant nowadays, whereas the latter is still a practice among the Arabs, but seems irrelevant in Malaysia where no cases have been reported. 
consummation of the marriage, is not entitled to inherit his or her biological father's estate on the ground that no legitimate blood relationship existed between them.

\section{THE PRINCIPLE OF ISTIŞHĀB AS A SOURCE OF ISLAMIC LAW}

The principle of istishâb is applicable to uphold the status quo due to the non-existence of new proof. It is a matter of presumption and applying it means that the existing ruling remains effective due to the unavailability of newly contrary evidence. In Islamic law, a ruling is based on facts and evidences and hence, as a result of the absence of newly different facts and evidences, the existing ruling remains valid and no change of ruling would take place. ${ }^{13}$

The term istishâb originates from the root word sahaba which means to accompany or to escort. The word istașhaba according to alZuhaylî, literally implies a request of companionship. ${ }^{14}$ It is observed that there exists connection between the literal and technical meanings. Al-Sarakhsî has defined it technically to mean the presumption of continuance of an earlier rule or its continued absence. ${ }^{15}$ Therefore the connection between the two lies on the fact that the old circumstance continues or accompanies the present without any change as far as the ruling is concerned. In other words, the original ruling for the old circumstance continues or accompanies the present to stay valid, due to the absence of any change to the present circumstance. According to Kamali, istiṣhâb denotes a rational proof which may be employed in the absence of other indications; specifically, those facts, or rules of law and reason, whose existence or non-existence had been proven in the past

\footnotetext{
13 See al-Khuḍarî, Sheikh Muhammad, Ușûl al-Fiqh, Beirut: Dâr al-Fikr, 1988, p. 356.

14 Muștafâ, al-Mucjam al-Wasît, p. 502 and al-Zuhaylî, Wahbah, Ușûl alFiqh al-Islâmî, Beirut: Dâr al-Fikr al-Mucâșir, 1996, vol. 2, p. 859.

15 See Nyazee, Imran Ahsan Khan, Islamic Jurisprudence (Ușûl al-Fiqh), Islamabad: The International Institute of Islamic Thought, 2000, p. 236.
} 
and which are presumed to remain so for lack of evidence to establish any change. ${ }^{16}$

The principle of istishâb is deduced from some Qur'anic verses ${ }^{17}$ which state a general guideline that everything in the universe is created for mankind and hence, mankind is allowed to use it unless there is evidence to the contrary i.e. mankind is not allowed to use. According to Shacbân, the verses show that Allah s.w.t has subjected everything in the universe to mankind and this indicates that it is permissible for mankind to use and to take everything in the universe. ${ }^{18} \mathrm{Al}$-Zuhaylî explains that the first verse indicates that the original ruling of anything that benefits mankind is permissible unless there is other dalîl indicating the contrary. ${ }^{19}$

Furthermore, there is a hadith of the Prophet s.a.w with regard to the question of validity of wudû ' when one is uncertain whether his wudûu' is still valid or has been vitiated. The Prophet (p.b.u.h) advised "Do not move away until you hear a sound or you smell some gas." 20 The hadith shows that the original ruling remains effective because a newly different fact cannot be established. These proof from the Qur'ân and the hadith show the concept of istishâab principle in preserving the original ruling unless and until any established evidence to the contrary is available. ${ }^{21}$

The principle is applicable as the last dalîl in cases in which no ruling is found in any other evidence. ${ }^{22}$ Al-Khawarizmî states that in issuing a fatwa, a muftî can apply istiṣhâb only after he could not find

16 Kamali, Mohammad Hashim, Principles of Islamic Jurisprudence, $2^{\text {nd }}$ revised ed., Malaysia: Ilmiah Publisher Sdn. Bhd., 2004, p. 297.

17 See al-Qur'ān, 2: 29 to the effect "He it is Who created for you all that is on earth” and al-Qur ān, 45: 13 to the effect “And He has subjected to you all that is in the heavens and all that is in the earth."

18 Shacbân, Zakiy al-Dîn, Usûl al-Fiqh al-Islâmî, Kuwait: Faculty of Laws and Sharîcah, University of Kuwait, n.d., p. 207.

19 Al-Zuhaylî, Wahbah, Uṣûl al-Fiqh al-Islâmî, vol. 2, pp. 861 \& 862. Ibn Qayyim al-Jawziyyah, Iclâm al-Muwaqqicîn 'can Rabb al-cÂlamîn, Beirut: Dâr al-Jayl, n.d., vol. 1, p. 340.

21 See al-Ghazâli, Abû Hâmid Muhammad bin Muhạmmad bin Muhammad, al-Mustașfâ min 'Ilm al-Ușûl, $1^{\text {st }}$ ed., Beirut: Dâr al-Ihyâ‘ al-Turâth alcArabî, 1997, vol. 1, p. 197.

22 Zaydân, 'Abd al-Karîm, al-Madkhal li Dirâsah al-Sharî́ah alIslâmiyyah, Beirut: Mu‘assasah al-Risâlah, 2001, p. 179. 


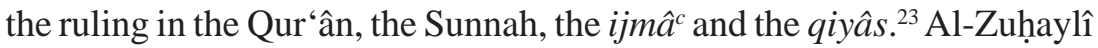
further explains that it is unanimously agreed by Muslim scholars that istishâb cannot be applied when the ruling is established by other Sharîa $a h$ evidence. ${ }^{24}$ If there is a conflict between istișhâb and other evidences, the latter takes priority. ${ }^{25}$ This is because the principle lies on mere presumptions and probabilities whereas other evidences are based on facts.

\section{ISTISTHĀB IN THE CASE OF A MISSING PERSON AND ISSUES OF SUCCESSION}

According to al-Zuhaylî, a missing person or in Arabic al-mafqûd is a person who has been found missing or who has disappeared from the area where he lives for a certain period and his life and death are unknown. ${ }^{26} \mathrm{Al}$-Bahûtî provides a general understanding of the nature of a missing person as he defines it as a person whose information about his life and death are unknown. ${ }^{27}$ The reason for the disappearance could be earthquake, shipwreck, calamity, war, kidnapping, loss or epidemic.

The relevant Islamic legal maxim that could be applied for the missing person case is "the original state of a thing remains effective until there is evidence to the contrary." ${ }^{28}$ Applying this maxim, a missing person is deemed alive because there is no evidence showing his death.

\footnotetext{
23 Al-Zuhaylî, Ușûl al-Fiqh al-Islâmî vol.2, p. 860.

$24 \quad$ Ibid., p. 860.

$25 \quad$ Kamali, Principles of Islamic Jurisprudence, p. 230. Al-Zuhaylî, Ușul al-Fiqh al-Islâmî, vo. 2, p. 868. See also Zahrah, Muhammad Abû, Ahkâm al-Tarikât wa al-Mawârîth, Kaherah: Dâr al-Fikr al-cArabî, n.d., p. 220.

Al-Bahûtî, Manșûr bin Yûnus bin Idris, Kashshâf al-Qinấc can Matn al-Iqnâ ${ }^{c}$ li al-Hajjâwî, $1^{\text {st }}$ Edition, Beirut: Dâr al-Ihyâa' al-Turâth al'Arabî, vol.4, p. 449. Zaydân, 'Abd al-Karîm, al-Madkhal li Dirâsah al-Sharî́ah alIslâmiyyah, p.178. Another three Islamic legal maxims that are applicable in applying the principle Istiṣhâb are the original rule for all things is permissible, there is no presumption of liability against anyone and certainty does not give way to doubt. See also Nyazee, Islamic Jurisprudence, p. 237.
} 
Therefore, his property should not be distributed to his legal heirs because applying the above maxim, he is deemed alive. The same applies to the case where a missing person is among the legal heirs of a praepositus. The estate should not be distributed by simply ignoring his survival because the maxim states that he is presumed alive.

However, a question arises as to how long the presumption of a missing person being alive remains effective if the evidence of his death or life is yet to be found. Muslim scholars take into consideration the life span of a man in order to determine the death of the missing person if evidence of his death or life could not be established. ${ }^{29}$ This is based on the argument that human life cannot continue indefinitely. On this basis, determining the life-span of a man is significant because a judicial decree of his death could be obtained when his life-span has passed. ${ }^{30}$

Muslim scholars differ in determining the life-span of a man because the life-span itself actually depends on the natural surroundings of the area in which the person lives. Accordingly, Abû Hanîfah puts it as one hundred and twenty years and Abû Yûsuf, hundred years. ${ }^{31}$ Some other Hanafîs, prefer it to be decided by the Ruler using his discretion which should be based on his ijtihâd by looking at the people of the missing person generation and by considering the missing person as the last person of that generation who is still alive. ${ }^{32}$

Imâm Mâlik on the other hand put it as four years based on the opinion of 'Umar al-Khațâb which was reported in al-Muwatța' by Sacîd ibn Musayyab from 'Umar that he said to the effect: "Any woman whose husband is missing and she does not know his whereabouts, needs to wait until four years and subsequently she needs to observe the ${ }^{c} i d d a h$

$29 \quad$ Al-Kalwadhânî, Najm al-Hudâ Abî al-Khațâb Mahfûdz bin Ahmad bin al-Ḥasan, al-Tahdhîb fî c Ilm al-Farâ' 'ị wa al-Wașâyâ, edited by alKhawlî, Muhammad Aḥmad, Riyâḍ: Maktabah al-cAbîkân, 1995, pp. 257-263.

30 Coulson, N.J., Succession in the Muslim Family, London: Cambridge University Press, 1971, p. 196.

31 Al-Kâsânî, Imâm 'Alâ‘ al-Dîn Abî Bakr ibn Mas'ûd, Badâ ' $i^{c}$ al-Sanâ ‘ ${ }^{c}{ }^{c}$ fî Tartîb al-Sharâ' ${ }^{\prime}{ }^{c}$, edited by Sheikh 'Alî Muhammad Mucawwaḍ and Sheikh cÂdil Aḥmad ${ }^{\mathrm{C} A b d}$ al-Mujawwid, vol. 8, Beirut Dâr al-Kitâb al-c'Tlmiyyah, 1997, p. 316.

$32 \quad$ cAțiyyah, p. 712- 713. 
period of four months and ten days before she can marry." 33 In fact, the Mâlikîs state that after four years a husband is found missing, his wife is allowed to apply for the decree of his death from the court. ${ }^{34}$ It is argued that four years is given because the disappearance of her husband causes hardship to her as far as her financial support and maintenance are concerned. ${ }^{35}$ Therefore, when the decree of death is issued, the wife is allowed to remarry.

According to the Shâficîs, applying istishâhb means that the missing person is deemed alive and consequently his property would not be distributed unless and until the evidence of his death is found. In the absence of such evidence and after the lapse of a length of time which would give rise to a strong belief that no one of the missing person's age would be alive, the Ruler is allowed to perform ijtihâd and accordingly issue a decree of his death. ${ }^{36}$ In other words, the matter is decided by the ijtihâd of the Ruler and they do not stipulate any duration of time as a life span to presume the death of the missing person. ${ }^{37}$

To the Hanbalîs, it is ninety years and according to another opinion, it is a matter of the ijtihâd of the Ruler. ${ }^{38}$ If a person is found missing in the circumstance that raises strong probability of his death, such as in war, epidemic, building collapse, earthquake or shipwreck, the Hanbalîs put four years of missing as the limit for the court to declare the death of the person. ${ }^{39}$ However, prior to that, the necessary search and

33 See Dawûd, Ahmad Muhammad 'Alî, al-Huqûq al-Mutacalliqah bi al-Tarikah bayn al-Fiqh wa al-Qânûn, 'Ammân: Dâr al-Thaqâfah, p. 534. See also al-Khuḍarî, Aḥmad Kâmil, al-Mawârîth al-Islâmiyyah, $2^{\text {nd }}$ edition, Egypt: Mațbacah al-Tawakkal, 1950, pg. 18. This is based on the opinion of ' Umar al-Khatțâb who ordered that a woman whose husband was possessed by an evil spirit to wait for 4 years from the moment she reported her case to him. See Barrâj, p. 661. 'Ațiyyah, pp. 713-716. Al-Sharbînî, vol. 4, p. 46. See al-Hașrî, Ahmad, al-Tarikât wa al-Waṣâyâ fî al-Fiqh al-Islâmî, 'Ammân: Maktabah al-Aqșâ, 1972, p. 192.

Al-Bahûtî, Kashshâf al-Qinấc can Matn al-Iqnâc li al-Hajjâwî, p. 449. This is based on the hadîth to the effect "the ages of my people are between 70 and 90 years old.” See Ibn Qudâmah, al-Mughnî wa alSharḥ al-Kabîr calâ Matn al-Muqnic, p. 208. Al-Bahûtî, p. 449 and al-Khuḍarî, al-Mawârîth al-Islâmiyyah. 
enquiry of the missing person's status must be done. If it fails to provide any indication that he is still alive, the court may therefore proceed to issue a decree of his death. ${ }^{40}$ If he is found missing in the situation which does not apprehend his death, according to another opinion, the matter is left upon the ijtihâd of the Ruler on the passage of time after which none of the men of his age (contemporaries) is alive. ${ }^{41}$

According to al-Kalwadhânî, it is the opinion of Abû Hanîfah, Imâm Mâlik and Imâm al-Shâficî that the matter is left upon the ijtihâd of the Ruler who must be guided by the fact that no man of his similar condition is alive. ${ }^{42}$ Furthermore, Badrân quoted the opinion of al-Zaylâcî who states that the matter should be left to the Ruler to decide after necessary enquiries, searches, investigations and ijtihâd have been carried out and the decision must serve the maslahah protected by the Sharîn $a h{ }^{43}$

\section{DETERMINATION OF THE SHARES OF LEGAL HEIRS INVOLVING A MISSING PERSON}

One of the conditions of succession is the undisputed survival of legal heirs at the time the praepositus dies. ${ }^{44}$ In this regard, if one of the legal heirs is a person who is found missing prior to the praepositus' death, neither the estate would be distributed to him nor is he excluded from inheritance. This is because his survival is not definite. In fact, his survival is based on the presumption of continuity or istishâb which is not absolute.

$40 \quad$ See Hussein, Aḥmad Farrâj, Nizâm al-Irth fî al-Tashrî́c al-Islâmî, Iskandariyah: Dâr al-Jâmicah al-Jadîdah, 2003, p. 303, 'Ațiyyah, p. 716 and Coulson, p. 196.

41 See Ibn Qudâmah, al-Mughnî wa al-Sharh al-Kabîr calâ Matn alMuqnic, Beirut: Dâr al-Fikr, 1992, pp. 206-208. See also Tanzilur Rahman, A Code of Muslim Personal Law, Karachi: Islamic Publishers, vol. 2, pp. 575-577.

42 Al-Kalwadhânî, p. 259.

43 Badrân, Abû 'Aynayn Badrân, Ahkâm al-Tarikah wa al-Mawârîth, Iskandariyah: Mu'assasah Shabâb al-Jâmicah, 1981, p. 307.

$44 \quad$ Zahrah, Ahkâm al-Tarikat, p. 84. 
Apart from that, his death is not proven.$^{45}$ Therefore, there is the possibility that he is dead prior to the death of the praepositus and accordingly he is not entitled to the estate. Hence, the estate of the praepositus should not be wholly distributed to the indisputably existing legal heirs because of the possibility that the missing person is still alive. His survival would likely affect the entitlement of others.

The right of a missing person as an heir to the estate of the praepositus should be preserved. This is because his survival or death at the moment the deceased passes away could not be ascertained. Therefore, two principles are applicable i.e. the present heirs take minimal portion and the reservation of the remaining shares. ${ }^{46}$ This is to ensure that every rightful recipient should get what he or she deserves and no single right is neglected.

In order to apply the two principles, two presumptions must be made i.e. the missing person survives the praepositus and the missing person predeceases the prapeositus. ${ }^{47}$ For further explanation, an illustration of the application of the principles is shown in the case when a person dies and he is survived by a mother (M), a wife (W), a daughter (D) and a germane sister (GS). The daughter is found missing. The estate is valued at RM240,000.00.

\footnotetext{
45 Sâbiq, al-Sayyid, Fiqh al-Sunnah, Kaherah: Dâr al-Fath li al-'Iclâm al'Arabî, p. 293.

46 See al-Baltâjîi, Muhammad, al-Mîrâth wa al-Wasiyyah, al-Qâhirah: Dâr al-Salâm, 2007, p. 138, Barrâj, p. 665 and al-Sharbînî, vol. 4, p. 47 and Coulson, pp. 198-199.

47 See al-Bardîsî, Muhammad Zakariyâ, al-Mîrâth, Kaherah: Dâr alNahụah, 1969, pp. 65-70.
} 
a) Presumption of his survival

\begin{tabular}{|c|c|c|r|}
\hline $\begin{array}{c}\text { Legal } \\
\text { Heirs }\end{array}$ & Portions & $\begin{array}{c}\text { 24 (Common } \\
\text { Denominator) }\end{array}$ & $\begin{array}{c}\text { RMRM240,000 } \\
\text { (Total Estate) }\end{array}$ \\
\hline $\mathrm{M}$ & $1 / 6$ & 4 & RM40,000 \\
\hline $\mathrm{W}$ & $1 / 8$ & 3 & RM30,000 \\
\hline $\mathrm{D}$ & $1 / 2$ & 12 & RM120,000 \\
\hline GS & Residue & 5 & RM50,000 \\
\hline Total & & $\mathbf{2 4}$ & RM240,000 \\
\hline
\end{tabular}

b) Presumption of death

\begin{tabular}{|c|c|c|c|}
\hline $\begin{array}{c}\text { Legal } \\
\text { Heirs }\end{array}$ & Portions & $\begin{array}{c}\mathbf{1 2} \text { (Common } \\
\text { Denominator) }\end{array}$ & RM240,000 \\
\hline $\mathrm{M}$ & $1 / 3$ & 2 & $2 / 12 \times \mathrm{RM} 240,000=\mathrm{RM} 40,000.00$ \\
\hline $\mathrm{W}$ & $1 / 4$ & 3 & $3 / 12 \times \mathrm{RM} 240,000=\mathrm{RM} 60,000.00$ \\
\hline $\mathrm{GS}$ & $1 / 2$ & 6 & $6 / 12 \times \mathrm{RM} 40,000=\mathrm{RM} 120,000.00$ \\
\hline Total & & $\mathbf{1 1}\left({ }^{\mathbf{c}}\right.$ Awl) & RM220,000.00 \\
\hline
\end{tabular}

The present heirs take minimal shares means that mother takes RM40,000.00, the wife takes RM30,000.00 and the germane sister takes RM50,000.00. ${ }^{48}$ The remaining RM120,000.00 is reserved until the actual position of the missing daughter, whether she survives or predeceases the praepositus is known. If evidence is found that she survives the praepositus, the whole RM120,000.00 is given to her. And if it established that she predeceases the praepositus, the reserved RM120,000.00 is used to maximize the amount that every legal heir would rightfully receive. ${ }^{49}$

See 'Aysawî, Ahmad 'Aysawî, Ahkâm al-Mawârîth fî al-Sharî́cah alIslâmiyyah, Egypt: Jâmicah Ibrâhîm Kulliyyah al-Huquûq,1954, p. 161. See also Ibn Qudâmah, al-Mughnî wa al-Sharh al-Kabîr calâ Matn al-Muqnic , pp. 209-211.

See Hamdî, Kamal, al-Mawârîth wa al-Hibah wa al-Waṣiyyah, Iskandariyyah: Dâr al-Mațbûcat al-Jâmiciyyah Kulliyyah al-Huqûq, 1987, p. 102. Rahman quotes s. 45 of the Egyptian Law of al-Mawârîth No. 77 of 1943 "the share of an untraceable person in ancestor's property shall be withheld for him. When he presents himself alive he shall take his share. If the order declaring him dead is passed, his share shall be divided among those heirs who are alive at the time of the 
To the Shâfi 1 îs, if there is no legal heir except the missing person, the estate would not be distributed until and unless his survival or death is ascertained. If other legal heirs exist, they would take only minimal portions from two presumptions that he is either alive or he is dead and the reservation of share. ${ }^{50}$

\section{ISTIȘHĀB ACTS AS BOTH A SHIELD AND A SWORD?}

The above illustration explains the method of distributing the estates of the praepositus which involves a missing legal heir. It explains the distribution before and after the evidence of his survival or death. However, a problem arises when the evidence of his death or survival is not found and the court, assisted by circumstantial evidence and after resorting to the principle of istișhâb and carrying out the necessary investigation, issues a decree of his death. In other words, Muslim scholars are in disagreement on the issue of the date of death: is it the date on which he went missing or the date of the decree.

The cause of the disagreement is their divergent views over the issue of whether the principle of istiṣhâb could be used to protect one's established right only or to acquire new rights as well. To the Hanafîs and the Mâlikîs, as far as the right of a missing person to inherit from a praepositus is concerned, istiṣhâb is not applicable to acquire new rights. ${ }^{51}$ For the rulings which are not in his favour such as inheritance to his wealth by others, he is presumed alive and for the rulings which are in his favour such as his right of inheritance towards others' estates, he is presumed dead. ${ }^{52}$ Al-Kâsânî argues that since the life of the missing

order passed regarding his death. If he returns after the order declaring his death has been passed, he shall be entitled to take back the share remaining (in hand) with the heirs.” See Rahman, Tanzil-ur, A Code of Muslim Family Law, Karachi: Islamic Publishers, vol. II, 1980, p. 577. See also Dawûd, Dawûd, Aḥmad Muhammad 'Alî, al-Huqûq alMutacalliqah bi al-Tarikah bayn al-Fiqh wa al-Qânûn, p. 539. Al-Sharbînî, vol. 4, p. 47.

Al-Kâsânî, vol. 8, p. 313. See also Ḥamdî, Kamal, al-Mawârîth wa alHibah wa al-Wasiyyah, p. 100.

'Uthaymin, Ibn et., al-Majmûc al-Nafîs fî Fiqh al-Mawârîth wa yalîhi Majmû́cfatâwâ Mu'âsarah fî al-Mawârîth, Kaherah: Dâr Ibn Jawzî, 2007, p. 599. 
person is based on a mere presumption, therefore it cannot establish and even it impedes any mutual rights of inheritance. ${ }^{53}$

Conferring a right of inheritance to him means the entitlement of present heirs might be reduced. In other words, it causes harm to them because their portions are reduced with the presence of the missing person. ${ }^{54}$ This means that when the court issues the judicial decree of his death, he is therefore considered predeceasing the praepositus and as a result, is not entitled to inherit. Coulson views that, in contemplation of law, for purpose of succession to the estate of others, the date of death of missing person is the date of his disappearance. ${ }^{55}$ In other words, the effective date of death of the missing person as far as his right of inheritance towards other's estate is concerned, is the date he went missing. Istishâb is therefore used to prevent harm according to the Hanafîs and the Malikîs.

However, they hold different views with regard to the estates of the missing person as far as istishâhb and judicial decree are concerned. Applying istishâb means that the person is presumed alive because it is the original fact before he is found missing. Istiṣhâb is therefore used to protect his estates from being inherited by others. ${ }^{56}$ Therefore, he is considered dead the moment the decree is issued by the court. ${ }^{57}$ Any legal heir of the missing person who dies before the judicial decree is issued is considered predeceasing him and hence, is not entitled to inherit.

The established right of the missing person cannot be taken by the legal heirs by way of presumption of his death. Coulson comments that, in contemplation of law, therefore, the date of a missing person's death, for purpose of succession to his own estates, is the date of the judicial decree. ${ }^{58}$ In other words, istișhâb is only used to protect the established rights but not to acquire new rights.

On the other hand, the Shâficîs and the Hanbalîs hold the view that istișâab can be used as a means of defense i.e. to defend the

\begin{tabular}{ll}
\hline 53 & Al-Kâsânî, vol. 8, p. 313. \\
54 & cAtiyyah, p. 724. See also Dawûd, Ahmad Muhammad cAlî, al-Huqûq \\
& al-Mutacalliqah bi al-Tarikah bayn al-Fiqh wa al-Qanûn, p. 535. \\
& Coulson, p. 200. \\
55 & 'Aysawî, Ahmad 'Aysawî, Ahkâm al-Mawârîth fî al-Sharî̀cah al- \\
56 & Islâmiyyah, Egypt: Jâmicah Ibrâhîm Kulliyyah al-Huqûq,1954, p. 161. \\
& Al-Kâsânî, p. 316. \\
57 & Coulson, p. 200.
\end{tabular}


continued existence of an attribute and as a means of proving or acquiring new rights. ${ }^{59}$ As praepositus, istișhâb is used to protect his estates from being inherited by others. Therefore, when the judicial decree of his death is issued by the court, only legal heirs who are alive at that moment are entitled to inherit whereas those who die prior to the date of the judicial decree have no right of inheritance. ${ }^{60}$

This is in agreement with the opinion of the Hanafîs and the Mâlikîs. However, with regard to his right of succession towards the praepositus' estate, the Shâfi î̀s and the Hanbalîs are of the view that istishâa can used as a means of acquiring rights as well. This is based on the argument that the missing person's survival is the established state before he is found missing. ${ }^{61}$ Therefore, his date of death is effectively the date of the judicial decree and consequently, he is entitled to inherit from the praepositus because the latter is dead when the missing beneficiary declared dead, is found alive.

However, if the missing person is proven alive and he returns after the issuance of the decree of his death and his estate has been distributed accordingly, or his right as a legal heir has been cancelled, he is allowed to take whatever is remaining in the possession of those who legally received it. He has no right to claim the properties which have been consumed or alienated because the distribution is lawful. ${ }^{62}$ In other words, a judicial decree of death naturally ceases to be effective if he is subsequently found to be alive. ${ }^{63}$

In conclusion, the Shâfi ${ }^{1} \hat{s}$ and the Hanbalîs use istiṣhâb as both a sword and a shield that is to protect as well as to acquire rights (li aldafc wa li al-kasb). On the other hand, the Hanafîs and the Mâlikîs view that it should act as a shield to protect missing persons' rights (li al$d a f^{c}$ ) from being acquired by others but not as a sword i.e. as a means for the missing person to acquire rights from the praepositus (li al-kasb).

\footnotetext{
59 See al-Zuhaylî, Ușûl al-Fiqh, p. 868 and Kamali, 383.

60 Al-Sharbînî, vol. 4, p. 46-45, al-Zuhaylî, vol. 8, p. 420.

61 Al-Zuhaylî, al-Fiqh al-Islâmi wa Adillatuhu, Damshiq: Dâr al-Fikr, 1989, vol. 8, p. 422.

62 See Dawûd, p. 539, 'Atịyyah, p. 728, 'Aysawî, Ahkâm al-Mawârîth fî al-Sharîcah al-Islâmiyyah, pp. 160-161 and Coulson, p. 197.

63 Coulson, p. 197.
} 


\section{THE MALAYSIAN LAWS ON SUCCESSION INVOLVING MISSING PERSONS}

In Malaysia, based on section 108 of the Malaysian Evidence Act, ${ }^{64}$ a person is presumed dead if he is not heard for 7 years by those who would naturally have heard of him if he had been alive. This provision which is of general application applies in cases of succession to a missing person's estates and the right of a missing person to inherit from others. This provision was applied by the Malaysian High Court in the case of Ridzwan Bin Ibrahim. ${ }^{65}$ The court granted the application by the applicant, Ridzwan bin Ibrahim for the declaration that Sheikh Mohamed bin Sheikh Ali be presumed dead. The latter was believed to have died sometime in 1973 in Hijâz based on the general statement of his death. An affidavit also disclosed the fact that after he left Malaysia round about 1957, he had not since then returned to Malaysia. And since then, neither the applicant and nor his cousin who are considered as those who would naturally have heard of him if he had been alive, had received any information regarding his life and death

However, apart from section 108 of the Malaysian Evidence Act, the Syariah courts evidence enactment of states which is specifically legislated for the purpose to deal with the Islamic law matters, also provides similar provision. The example is section 80 of the Syariah Court Evidence (Federal Territories) Act, 1997 which provides that:

"When the question is whether a man is alive or dead, and it is proved that he has not been heard of for four years by those who would naturally have heard of him if he had been alive, the burden of proving that he is alive is shifted to the person who affirms it."66

The difference between the two statutory provisions is that $\mathrm{s}$. 108 of Malaysian Evidence Act requires seven years of missing whereas s. 80 of the Syariah Court Evidence (Federal Territories) requires four years before the court can issue the certificate of death. In this regard,

\begin{tabular}{ll}
\hline 64 & Act 56. \\
65 & [2002]1 MLJU 418. \\
66 & Ibid.
\end{tabular}


the two provisions do not take into account the issue of the life-span of a man as discussed by Muslim scholars, before he or she is presumed dead. It is apparently the opinion of the Mâlikîs and the Hanbalîs who state that after four years of missing, the court can issue a decree of his death.

It is to be noted that the Hanbalîs are of the opinion that if a person is found missing in the circumstance that raises strong probability of his death such as in war, building collapse or earthquake, the four years of necessary search and enquiry of his life and death is sufficient before the declaration of his death is issued. The waiting period of four years is generally too short and should be applicable only in the situation envisaged by s. 21 of the Egyptian Law (Law no. 25) 1929, s. 205 of the Syrian Family Law and s. 177 of the Jordanian Family Law. ${ }^{67}$ Syrian Family Law provides that the decree of death can be issued only when he reaches 80 years old. The other two statutes provide that the matter should be left upon the ijtihâd of a Sharie Judge who abides by strict statutory guidelines in issuing such a decree. ${ }^{68}$

It is important to mention that in the case of a wife whose husband is found missing and she intends to remarry, the four years allowed according to the Mâlikîs, is due to the hardship suffered by the wife as far as financial support and maintenance are concerned. ${ }^{69}$ This is for the maslahah of the missing person as well as for those who are legally related to him especially his legal heirs.

Section 108 of Malaysian Evidence Act and section 80 of the Syariah Court Evidence (Federal Territories) Act, 1997 are silent over

Dawûd, Aḥmad Muḥammad 'Alî, al-Huqûq al-Mutacalliqah bi alTarikah bayn al-Fiqh wa al-Qânûn, pp. 536-537. The translation of the statutory provision of the Egyptian Law is "Where a person disappears in circumstances which raises a presumption of his death and due enquiries concerning him prove fruitless, a judicial decree of death may be issued when four years have elapsed since the date of disappearance.” See Rahman, Tanzil, pp. 578-579.

$68 \quad$ Ibid.

69 Barrâj, p. 662. However in Malaysia, some states enactments provide 7 years of the waiting period for the purpose of remarrying like s. 43(1) Islamic Family Law (Federal Territories) 1984 (Act 303) states "If the husband of any married woman has died or is believed to have died or has not been heard of over a period of 7 years or more, and the 
the date of death of the missing person, after the declaration of his death is pronounced by the court, either after four years or seven years. However, based on the two orders which had been issued by the Malaysian High Court, it is clear that the date of death is the date person went the missing. ${ }^{70}$ Therefore, this is clearly not the opinion of the Shafi ${ }^{\circ} \hat{s}$ but the opinion of the Mâlikîs and Hanafîs.

It is indisputable that establishing the date of death of a missing person is significant because it would determine whether the missing person has right to inherit others' estates who die after he goes missing. Similarly the date of death would also ascertain whether others who die after his missing but prior to the pronouncement of his death, have right to inherit his estate. In other words, knowing whether it is the date of missing or the date of the judicial decree as his date of death is important in order to ascertain the rightfully entitled legal heirs under the Farâ 'id system.

\section{JURISDICTIONAL CONFLICT BETWEEN CIVIL COURTS AND SYARIAH COURTS TO GRANT A DECLARATION THAT A MUSLIM IS PRESUMED DEAD}

Despite the unambiguous enumeration in the Federal Constitution, a conflict arises as to whether the Syariah courts are competent to determine disputes pertaining to Muslim succession or whether this falls under the civil courts' jurisdiction. Commenting on the judgment by the

circumstances are such that he ought, for the purpose of enabling the woman to remarry, to be presumed in accordance with Hukum Syarak to be dead, but a death certificate under the Births and Deaths Registration Ordinance 1957 cannot be obtained, the Court may, on the application of the woman and after such enquiry as may be proper, issue in the prescribed form a certificate of presumption of death of the husband, and thereafter the woman shall be at liberty to remarry in accordance with the provisions of this Act.” S. 41(1) Islamic Family Law Enactment (Kelantan) 1983 provides similar provision.

70 See Harun, Wan Abdul Halim Wan, Pengurusan Dan Pembahagian Harta Pusaka, Kuala Lumpur: Dewan Bahasa dan Pustaka, 2008, p. 31. 
Malaysian High Court in Ridzwan Bin Ibrahim, ${ }^{71}$ Pawancheek Merican states:

"As to the mode of beginning such proceedings, the Syariah Court Civil Procedure (Federal Territories) Act, 1998 provides that such proceedings shall be by summons. It is further provided in the procedural statute that the proceedings stipulated in its Second Schedule shall be begun by application includes an application for presumption of death. The Syariah Civil Procedure Act in no uncertain terms confers power on the Syariah courts to grant orders of presumption of death, and by virtue of article 121(1A) of the Federal Constitution, it would appear that the civil courts cannot encroach upon this jurisdiction of the Syariah court. Despite this clear expression of jurisdiction, a civil court in a recent decision held that it had jurisdiction to grant such a declaration that a Muslim be presumed dead."72

It appears from the court's decision that declaring a Muslim's death on presumption is within the civil court's jurisdiction because such a declaration constitutes part of the administration of estate which is clearly listed in item 4(e) of Federal List, Federal Constitution. The learned judge clearly stated that the application was allowed because the applicant may have to seek again the jurisdiction of a civil court in order to obtain the letters of administration. In other words, the court understood that the matter is part of the matters of probate and letters of administration and hence, the court has jurisdiction over it. ${ }^{73}$

The jurisdictional conflict between Malaysian civil courts and Syariah courts pertaining to matters of succession of a deceased Muslim's estate are discussed in detail in the case of Jumaaton \& Raja Delila v Raja Hizaruddin. ${ }^{74}$ This was an appeal heard by the Syariah Appeal

\footnotetext{
71 [2002] 418 MLJU 1.

72 Marican, Pawancheek, Islamic Inheritance Laws in Malaysia, Kuala Lumpur: Malayan Law Journal, 2004, p. 72.

73 See [2002] 1 MLJU 418.

$74 \quad$ [1998] 6 MLJ 557.
} 
Court, regarding an application for a declaration that the shares, including the income derived therefrom, in a company that were held in the name of the defendant (a son of the deceased) formed part of the deceased's estate.

The facts of the case are that two of the heirs, Jumaaton Zaiton bt Haji Awang and Raja Delila bt. Raja Nong Chik, applied to the Syariah High Court of the Federal Territory of Kuala Lumpur for a declaration against the defendant, Raja Hizaruddin b. Raja Nong Chik (a son of the deceased), that the 11,095,666 unit of shares (and the income derived therefrom) in Arensi Holdings (M) Bhd., which was registered in the defendant's name, was part of the estate of the deceased. They claimed that the property did not belong absolutely to him and must be distributed among the twelve legal heirs according to the farâ'i $i d$ system. ${ }^{75}$ The Syariah High Court held that it had no jurisdiction to hear the case under section 46(2) of the Administration of Islamic Family Law (Federal Territories) Act, 1993 (Act 505). ${ }^{76}$

The appellants subsequently appealed to the Federal Territory Syariah Appeal Court. On appeal, which upheld the decision of the Syariah High Court. The Syariah High Court had no jurisdiction on the basis that this was a matter of probate and the administration of the estate and therefore governed by the Probate and Administration Act, 1959. Such a matter is within the Federal List of the Ninth Schedule of the Federal Constitution and applicable to Muslims. ${ }^{77}$

The above decision was then referred to and adopted by the civil High Court in the case of In the Estate Of Tunku Abdul Rahman Putra Ibni Almarhum Sultan Abdul Hamid v. Tunku Khadijah bte Tunku Abdul Rahman Putra \& 2 Ors. ${ }^{78}$ The issues here were whether or not the High Court had jurisdiction to hear and determine a dispute arising out of the administration of the estate of a Muslim and whether or not it had jurisdiction to hear and determine the disputes pertaining to the validity of the marriage between the deceased and Chong, and the legitimacy of the third petitioner who was the child of the marriage. On the issue of jurisdiction, the High Court held that matters pertaining to

\begin{tabular}{ll}
\hline 75 & Ibid., p. 559. \\
76 & Ibid. \\
77 & Ibid., pp. 563- 565. \\
78 & [1999]1 AMR 30.
\end{tabular}


"probate and administration" do not fall within the civil jurisdiction of the Syariah courts as confirmed by the Syariah Appeal Board of the Federal Territory Syariah Court in Jumaaton \& Raja Delila v. Raja Hizaruddin. ${ }^{79}$

Arguments similar to those in the Jumaaton case were put forward contending that matters pertaining to probate and letters of administration are within the jurisdiction of the civil High Court by virtue of the Federal List in the Ninth Schedule of the Federal Constitution. ${ }^{80}$ According to the learned judge in this case, the Probate and Administration Act, 1959 is an Act of general application to both Muslims and nonMuslims. Unlike other statutes which contain a clause limiting their application to non-Muslims, such as section 2(2) of the Wills Act, 1959, section 2 of the Distribution Act 1958 and section 31 of the Adoption Act 1952, the Probate and Administration Act contains no such provision. ${ }^{81}$ The learned judge also relied on section 24 (f) of the Courts of Judicature Act 1964, which confers upon the High Court jurisdiction in respect of matters of "probate and administration." He further supported his contention by stating the predominant position of the provisions in the Courts of Judicature Act 1964, vis-à-vis other ordinary Acts of Parliament or written laws, other than the Federal Constitution as enumerated in section 4 of the Courts of Judicature Act 1964, which provides that in the event of inconsistency or conflict between the Courts of Judicature Act 1964 and any other written law other than the Federal Constitution, the Courts of Judicature Act 1964 shall prevail. ${ }^{82}$

However, with regard to questions of validity of marriage and legitimacy of children, the Court held that such matters are within the jurisdiction of the Syariah courts. The hearing was therefore stayed and all parties were directed to refer to the Syariah Court for a final and conclusive determination regarding these two issues. ${ }^{83}$

Observing the decision of the Syariah Appeal Court in the Jumaaton case, it appears that the basis of the judgment was that the matter in dispute was one of probate and administration of estate. The

\begin{tabular}{ll}
\hline 79 & Ibid., p. 31. \\
80 & Ibid., p. 34. \\
81 & Ibid., p. 35. \\
82 & Ibid., p. 34. \\
83 & Ibid., p. 37.
\end{tabular}


Court's view was that the determination of the shares in dispute, whether they constituted an asset of the deceased or not, was part of the process of probate and the administration of the estate. It appears that the Court did not consider this as an issue pertaining to a question of Islamic law to be determined by the Syariah court.

Mohamad Imam argues that the determination of persons entitled to shares, the extent of their shares and the distribution and apportionment of the properties of the estate are a single and composite process of the judicial administration of a deceased Muslim's estate. ${ }^{84}$ In other words, they constitute an integral part of the process of probate and administration of estate and all are included in the term of 'Islamic law relating to succession, testate and intestate' as stated in the State List of the Federal Constitution. ${ }^{85}$ He concludes that:

"So construed, what is excluded from para (i) of item 4(e) of the Federal List by para (ii) thereof, and what is included in item (l) of the State List is 'the entire body of the Islamic law of succession, testate and intestate' and that includes Islamic rules relating to probate and administration, and, therefore, fall within the jurisdiction of the Syariah High Court to the exclusion of the civil High Courts as enjoined by clause (1A) of Article 121 of the Federal Constitution." 86

The Federal Court adopted a new interpretation in the case of Latifah bte Mat Zin v. Rosmawati bte Sharibun \& Anor. ${ }^{87}$ In this case, the Court had to decide whether moneys in joint accounts of the deceased with the appellant in the Bumiputra Commerce Bank (BCB) and the Standard Chartered Bank constituted the assets of the estate of the deceased or, as claimed by the appellant was given to her as a gift. The Court had referred to the judgment in Jumaaton case and viewed

\footnotetext{
$84 \quad$ Imam, Mohamad, "Probate and Administration of a Muslim’s Estate in Malaysia- Legislative Competence and Syariah Court Jurisdiction,” Jurnal Undang-Undang Malaysia, vol. 2, 1998, pp. 131-132.

85 Ibid.

$86 \quad$ Ibid.

87 [2007] 5 MLJ 101.
} 
that the matter in dispute in that case i.e. whether company shares constituted part of the deceased estate, is not a matter of probate and administration but an Islamic law issue within the jurisdiction of the Syariah court. ${ }^{88}$

On this basis, the Court dismissed the appeal and held that the determination of that issue and the beneficiary or beneficiaries entitled to it and in what proportion, are within the jurisdiction of the Syariah court. ${ }^{89}$ The task of the civil court is to give effect to it in the grant of a letter of administration, and subsequently, in distributing the estate. ${ }^{90}$ Quite similar to what is proposed by Mohamad Imam, Abdul Hamid Mohamad FCJ states:

"We have seen that item 4(e)(i) of the Federal List, inter alia, provides that 'succession, testate and intestate; probate and letters of administration' are matters within the Federal jurisdiction. However, paragraph (ii) of item 4(e) removes 'Islamic personal law relating to ...gifts or succession, testate and intestate' from the Federal jurisdiction. This is followed by item 1 of the State List that, inter alia, provides that 'Islamic law and personal and family law of persons professing the religion of Islam, including the Islamic law relating to succession, testate and intestate' are matters that fall within the State List."91

It is important to mention that section 2 of the Probate and Administration Act, 1959 defines "probate” as a grant under the seal of

The Court referred to A Concise Dictionary of Law: Oxford Reference for the meanings of 'probate' and 'administration.' Probate is defined as a certificate issued by the court on the application of executors appointed by the will, to the effect that the will is valid and the executors are authorized to administer the deceased's estate. Administration is defined as the granting of letters of administration to the estate of a deceased person to administer when there is no executor under the will. See ibid., p. 16.

$89 \quad$ Ibid., p. 19.

$90 \quad$ Ibid.

91 Ibid., p.16. Abdul Hamid FCJ states "My learned brothers YA Dato" Arifin Zakaria FCJ and YA Dato`Agustine Paul FCJ have read this judgment in draft and have agreed with it.” See ibid., p. 20. 
the court authorizing the executor or executors therein named to administer the testator's estate. The "probate action" is defined in the same section as meaning a cause or matter in which a petition for probate or administration is contested by any person, and includes an application to alter or revoke any grant of representation. Furthermore, this section also defines "administration," with reference to the estate of a deceased person, as letters of administration issued by the court whether general, limited or with a will annexed or otherwise authorizing the person or persons therein named to administer the deceased person's estate in accordance with the law. Caroline Sawyer defines "administration of estates" as the process whereby the personal representatives collect in the assets of the estate and then meet the debts and liabilities and pay out the legacies and devices before distributing the residue, managing the estate as necessary in the meantime. ${ }^{92}$

It is to be noted that declaring a missing Muslim dead is a matter of Islamic personal law and it is related to the determination of rights of legal heirs under Islamic law of succession. Based on what is stated by Mohamad Imam and Abdul Hamid FCJ, it is submitted that this issue clearly pertains to a question of Islamic law and the determination of the legal heirs is regarded as part and parcel of inheritance law. According to Islamic law, the term legal heir is known in Arabic as "al-wârith" which constitutes the first essence of succession, without which succession would never take place. Therefore, to determine the status of the shares and the determination of the entitled legal heirs including the declaration of a person's death from the perspective of Islamic law is undoubtedly an issue of Islamic law.

It is therefore clear that such a matter is within the ambit of the Syariah courts' competency. This is supported by virtue of the State List of the Federal Constitution, which among other things enumerates that "the determination of matters of Islamic law" 93 is within the power and jurisdiction of the State Legislature and the Syariah court. ${ }^{94}$

\footnotetext{
${ }_{92}$ Sawyer, Caroline, Principles of Succession, Wills \& Probate, $2^{\text {nd }}$ edition, London: Cavendish Publishing Limited, 1998, pg. 329.

93 See the State List “...the determination of matters of Islamic law and the doctrine of Malay custom.”

94 See the case of In the Estate of Tunku Abdul Rahman, p. 37. In this case, the court had referred the disputes on the question of Islamic law i.e. the validity of marriage and the legitimacy of children.
} 


\section{CONCLUSION}

On the basis of the above discussion, it can be concluded that the determination of a Muslim's death in the uncertainty situation is a matter of Islamic law. It has been discussed in detail by Muslim scholars relying mainly on the principle of Ușûl al-Fiqh "Istiṣhâb." The absence of the material fact necessitates the judge to issue a declaration of his death which is based on presumption. This is not an easy task because it might affect matrimonial and financial rights of those who have blood or marriage or any other legally recognized relationships with the missing Muslim. Only qualified Muslim judges who are knowledgeable in Islamic law are able to scrutinize the issue in depth from Islamic perspectives. It is therefore submitted that the determination of Muslim's life and death and whether there is succession to his estates or not from the perspective of Islamic law, is not necessarily within the meaning of "probate and administration" as required by the Federal law. This process is best considered as a question of Islamic law and the Syariah court is therefore the only court with the competence to decide such an issue. Apart from that, the statutory provisions which provide in detail the laws to govern the missing person situation in matters of Muslim's succession like in Egypt, Jordan and Syria must be enacted in order to provide clear reference. 